\title{
Pemberdayaan Komunitas Pelaku Usaha Melalui Pembentukan KUBE Kuliner di Cangakan Karanganyar
}

\author{
Sarwoto $^{1}$, Lilik Wahyudi ${ }^{2}$, Joko Suyono ${ }^{3}$, Risgiyanti ${ }^{4}$ \\ ${ }^{1}$ Universitas Sebelas Maret \\ ${ }^{2}$ Universitas Sebelas Maret \\ ${ }^{3}$ Universitas Sebelas Maret \\ ${ }^{4}$ Universitas Sebelas Maret
}

sarwoto@staff.uns.ac.id, lilik.wahyudi@staff.uns.ac.id,jokosu_feb@staff.uns.ac.id, risgiyanti@staff.uns.ac.id

\begin{abstract}
Abstrak
Cangakan, Karanganyar, Jawa Tengah merupakan salah satu daerah di karanganyar yang banyak tumbuh kembang pelaku usaha kuliner. Lokasi Cangakan yang dekat dengan pusat kota dan alun-alun Kabupaten Karanganyar menjadikan daerah ini ramai dikunjungi warga untuk sekedar rekreasi ringan. Kondisi inilah yang menunjang tumbuh kembangnya usaha kuliner di Cangakan, Karanganyar mulai dari UMKM sampai dengan kuliner besar dan ternama yang buka cabang maupun franchise. Pelaku usaha kuliner yang dari UMKM didominasi oleh warga lokal Cangakan, Karanganyar yang saat ini mulai tergeser dari persaingan pasar. Permasalahan yang dihadapi oleh UMKM pelaku usaha kuliner di Cangakan, Karanganyar berkaitan dengan aspek kelembagaan, manajerial, dan permodalan.

Tujuan pengabdian ini adalah pemberdayaan dan penguatan kelembagaan komunitas pelaku usaha secara mandiri melalui pembentukan KUBE (Kelompok Usaha Bersama). Mitra komunitas pelaku usaha dalam program ini adalah komunitas pelaku usaha kuliner di Cangakan, Karangnyar. Metode yang dipakai untuk menyelesaikan masalah adalah pendidikan kepada masyarakat melalui pelatihan dan pendampingan pembentukan kelembagaan kelompok dalam KUBE Kuliner, sekaligus pemberdayaan anggota komunitas melalui pelatihan penguatan kelembagaan dan kewirausahaan.

Hasil akhir dari program ini adalah terbentuknya kelembagaan yang kuat dari komunitas pelaku usaha kuliner di Cangakan Karangnyar. Melalui KUBE yang terbentuk diharapkan dapat menjadi solusi dalam mengatasi permasalahan yang dihadapi.
\end{abstract}

Kata Kunci: pemberdayaan, pendidikan kepada masyarakat, pelatihan \& pendampingan

\section{PENDAHULUAN}

Cangakan, Karanganyar, Jawa Tengah merupakan salah satu daerah di karanganyar yang banyak tumbuh kembang pelaku usaha kuliner. Lokasi Cangakan yang dekat dengan pusat kota dan alun-alun Kabupaten Karanganyar menjadikan daerah ini ramai dikunjungi warga untuk sekedar rekreasi ringan. Kondisi inilah yang menunjang tumbuh kembangnya usaha kuliner di Cangakan, Karanganyar mulai dari UMKM sampai dengan kuliner besar dan ternama yang buka cabang maupun franchise. Menurut Menteri Pariwisata
Arief Yahya (2019). Karanganyar menawarkan sensasi wisata kuliner yang tak berkesudahan. Pusat Kuliner tersebar luas di kawasan sepanjang jalur utama. Mulai dari Palur, alun-alun dan plaza bisnis di Kelurahan Cangakan sampai dengan wisata kuliner di kawasan Taman Pancasila yang berjubel jumlahnya. Pelaku usaha kuliner yang dari UMKM didominasi oleh warga lokal Cangakan, Karanganyar sedangkan pelaku usaha kuliner yang besar merupakan cabang dari usaha yang sudah mapan dari luar kota maupun franchise.

Ekonomi, Sosial, dan Budaya

1019 
Trend wisatawan sekarang adalah datang ke suatu daerah wisata untuk mencari atau berburu makanan khas daerah tersebut dan tidak segansegan membayar mahal umuk menikmati suatu hidangan (Rismiyanto dan Danangdjoyo, 2015). Peran Kawasan Kuliner memiliki pengaruh yang besar pada perekonomian di suatu daerah, termasuk di Karanganyar karena untuk membangun sebuah kawasan industri kecil ini tidak membutuhkan modal yang besar dan mampu menyerap tenaga kerja banyak. Keberadaan Industri kecil juga memiliki kontribusi yang besar pada perkembangan perekonomian suatu daerah, karena dengan jumlah unit usaha yang banyak menciptakan lapangan pekerjaan serta mampu menyerap tenaga kerja sehingga berpotensi untuk mengurangi pengangguran di suatu daerah.

Masalah utama yang dihadapi oleh pelaku usaha kuliner di Cangakan Karanganyar adalah nilai tambah produknya yang relatif kecil. Hal ini disebabkan oleh modal yang kecil sehingga kesempatan berekspansi menjadi terbatas, sumber daya manusia yang relatif rendah sehingga tingkat kreatifitas dan inovasi produksi juga rendah, pemasaran yang dimiliki terbatas, sistem manajemen organisasi belum berjalan dengan baik. Dengan demikian proses pemberdayaan kawasan wisata kuliner di kawasan kuliner Cangakan Karanganyar menjadi keharusan dilakukan oleh Pemerintah Kabupaten Karanganyar di era otonomi daerah ini jika tidak ingin tertinggal dan tersingkir dari perkembangan ekonomi di era pasar bebas mendatang.

Permasalahan yang dihadapi pelaku usaha kuliner Karanganyar adalah tentang belum kuatnya posisi tawar kelompok usaha kuliner Karanganyar dalam struktur pasar dan perekomian yang ada. Mengingat kelompok usaha kuliner Kanganyar mulai tumbuh dan berkembang dan belum adanya asosiasi atau ikatan anatar kelompok sejenis yang bersifat permanen dan kuat, maka masalah kelembagaan perlu juga mendapatkan perhatian khusus agar keberlanjutan bisnis dapat dicapai. Kekuatan kelembagaan merupakan aspek yang penting dalam menjamin keberlanjutan bisnis di berbagai sektor (Yuniati dkk., 2017, Kusmanto dan Warjio, 2019, Khairunisa dkk., 2019). Ketika pelaku usaha mikro kecil dan menengah berjuang secara individual di dalam persaingan pasar yang sangat ketat tentu saja akan lebih sulit jika dibandingkan dengan ketika pelaku UMKM bersatu padu dalam sebuah asosiasi dalam menghadapi persaingan. Adanya kelembagaan atau asosiasi menjadikan UMKM berdaya saing yang lebih baik (Mustaqim dkk., 2018).

Pelaku usaha kuliner Karangnyar yang jumlahnya sekitar 250 an ini, saat ini masih berjalan masing-masing tanpa ada koordinasi serta komunikasi diantara pelaku usaha sejenis di satu kawasan yang sama. Maka dari itu, untuk meningkatkan posisi tawar dan daya saing pelaku usaha kuliner Karanganyar dengan pelaku kuliner pendatang dari luar Karangnyar, pemodal, dan struktur pasar kuliner yang lebih besar, maka pembentukan dan pemberdayaan kelembagaan pelaku usaha kuliner Karanganyar menjadi sebuah kebutuhan. Berkaitan dengan masalah ini, Program Pembedayaan Masyarakat ini akan memberikan solusi melalui pembentukan, pendampingan dan pemberdayaan sentra pelaku usaha kuliner Karangnyar menjadi sebuah Kelompok Usaha Bersama (KUBE) Pelaku Usaha Kuliner Karanganyar yang kuat dan berdaya saing, sehingga mampu membertahankan keberlanjutan bisnisnya.

Permasalahan-permasalahan yang dihadapai oleh pelaku usaha kuliner Karanganyar, berdasarkan studi awal. Maka solusi yang hendak diatawarkan untuk menyelesaikan permasalahan tersebut adalah: (1). Tim Pengabdian melakukan pemetaaan awal terhadap segala permasalahan dan potensi yang ada pada Mitra dengan pendekatan SWOT Analysis, (2). Melakukan FGD dengan para pengaku kepentingan yang ada yang berkaitan dengan Mitra, (3). Melakukan pelatihan dan pendampingan kepada Mitra, dan terakhir (4) adalah evaluasi dan monitoring hasi pendampingan pada Mitra.

Luaran yang dihasilkan dalam pengabdian ini adalah terbentunya kelembagaan pelaku usaha kuliner Cangakan Karangnyar dalam sebuah Kelompok Usaha Bersama (KUBE) Kuliner 45 Cangkan, Karanganyar beserta seperangkat kelengkapan organisasinya (pengurus, visi, misi lembaga dan program kerja).

\section{METODE}

Pelaksanaan pengabdian masyarakat ini menggunakan bentuk pendidikan kepada masyarakat. Bentuk pendidikan kepada masyarakat

Ekonomi, Sosial, dan Budaya

1020 
merupakan bentuk yang digunakan dalam pengabdian masyarakat yang berorientasi pada peningkatan sumberdaya manusia dalam mengelola dan menyelesaikan segala permasalahan yang dihadapi (Riduwan, 2016). Berdasarkan jenis kegiatan dalam bentuk pendidikan kepada masyarakat, Tim Pengabdi menggunakan pelatihan dan pendampingan UMKM untuk pelaksanaan transfer knowledge kepada UMKM dalam rangka peningkatan kualitas sumberdaya manusia pelaku UMKM kuliner Cangakan, Karanganyar.

Pelatihan yang dilaksanakan pada Program Pengabdian Masyarakat ini adalah Pelatihan Penguatan Kelembagaan dan Kewirausahaan bagi UMKM. Pelatihan dilaksanakan dengan pendekatan role play agar peserta pelatihan mudah dalam memahami substansi pelatihan sehingga termotivasi untuk mengimplementasikan secara nyata.

Selanjutnya, tindaklanjut dari pelatihan adalah pendampingan UMKM. Tim Pengabdi mendampingi UMKM dalam mengimplementasikan konsep-konsep yang diajarkan dalam pelatihan salah satunya dilakukan pendampingan dalam pembentukan Kelompok Usaha Bersama (KUBE) Kuliner, Cangakan, Karanganyar.

Berdasarkan sifatnya, pengabdian masyarakat ini termasuk ke dalam pengabdian masyarakat yang bersifat rintisan. Selama ini UMKM kuliner di Cangakan, Karanganyar belum mengenal adanya komunitas kelembagaan, sehingga Tim Pengabdi mengenalkan hal yang baru bagi UMKM kuliner di Cangakan, Karanganyar untuk mengatasi berbagai permasalahan yang dihadapi.

\section{HASIL DAN PEMBAHASAN}

\section{Pelatihan bagi UMKM}

Pelatihan yang diberikan kepada UMKM mitra adalah pelatihan penguatan kelembagaan dan kewirausahaan. Penguatan kelembagaan berkaitan dengan bagaimana merancang asosiasi pelaku usaha kuliner di Cangakan, Karanganyar, sedangkan kewirausahaan diberikan agar pelaku usaha kuliner di Cangakan, Karangayar dapat tumbuh berkembang menjadi wirausaha bukan sekedar pedagang kuliner.

Pelatihan disampaikan oleh Tim Pengabdi dengan dibantu oleh mahasiswa dan diikuti oleh UMKM kuliner di Cangakan, Karanganyar.

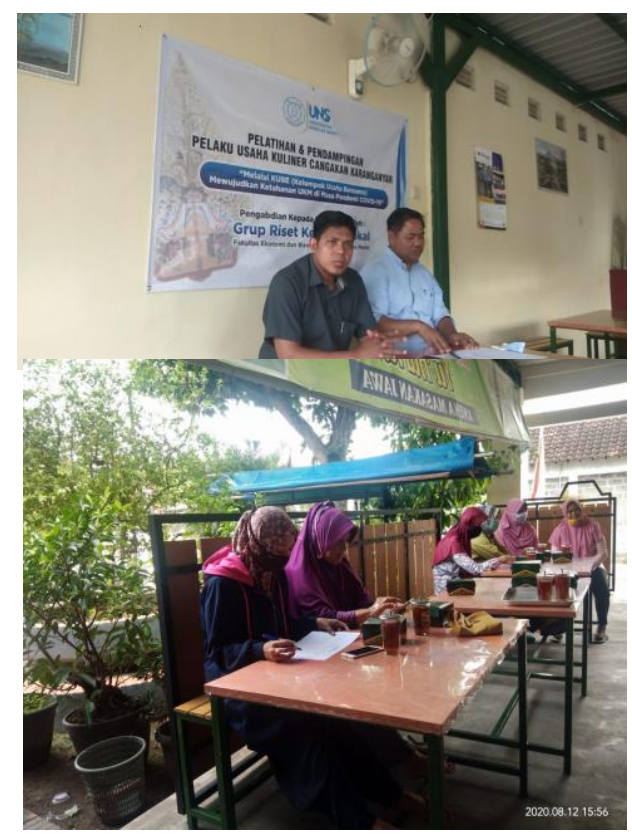

Gambar 1. Pelatihan Penguatan Kelembagaan \& Kewirausahaan

Materi pelatihan adalah penguatan kelembagaan dan strategi merumuskan tujuan usaha. Berkaitan dengan penguatan kelembagaan dikenalkan tentang organisasi, fungsi organisasi, dan peranan organisasi dalam menopang keberlangsungan usaha. Pada saat materi penguatan kelembagaan, peserta juga dikenalkan dengan "konsep uang setrika" yang menjadi pengantar pentingnya membina hubungan baik di dalam komunitas atau organisasi sehingga dapat menopang keberlanjutan usaha UMKM. Selanjutnya, juga dikenalkan tentang adanya Bank Kelompok yang dapat dilahirkan dari komunitas dengan prinsip dasar dari kelompok, oleh kelompok, dan untuk kelompok.

Sedangkan materi pelatihan berkaitan dengan kewirausahaan adalah strategi merumuskan tujuan usaha. Pada materi ini dikenalkan model merumuskan tujuan usaha bagi para pelaku usaha. Selama ini, diyakini bahwa merumuskan tujuan sekedar menyampaikan angan-angan ke depan dan semua peserta menyebutkan tujuannya abstrak. Maka dalam pelatihan ini disampaikan mengenai Tujuan harus "SMART" yang berarti Specific, Measurable, Achievable, Relevant, dan Timely 
(Meyer, 2003). Perumusan tujuan merupakan hal yang penting bagi organisasi (Barney, 2002; Taiwo dkk., 2016; Bowen, 2018). Tujuan akan menentukan langkah-langkah yang akan diambil oleh organisasi termasuk UMKM. Maka dari itu, diperlukan rumusan tujuan organisasi yang spesific artinya rumusan tujuan harus spesifik dan jelas, tidak abstrak dalam mencantumkan apa yang akan dicapai perusahaan. Meausurable berarti terukur, tujuan harus dapat diukur yang nantinya akan menjadi indikator kinerja bagi perusahaan. Achievable berarti tujuan yang dirumuskan adalah sesuatu yang dapat dicapai, artinya tujuan harus realistis. Meskipun terkadang rumusan tujuan sulit untuk dicapai tetapi harus tetap realistis bagi perusahaan dengan memperhatikan berbagai karakteristik yang melekat pada perusahaan. Relevant berarti tujuan harus sesuai dengan karakteristik dan visi yang dibangun perusahaan. Timely berarti harus jelas kapan tujuan itu ditargetkan tercapai sehingga mudah dalam mengukur keberhasilan pencapaian tujuan. Dalam pelatihan juga dikenalkan strategi merumuskan tujuan dengan metode backward yang berarti metode mundur. Dalam pelatihan, peserta masih kesulitan merumuskan tujuan, dengan bahasa lisan menyampaikan tujuannya mengalir saja. Perumusan tujuan dengan metode backward digambarkan sebagai berikut.

2

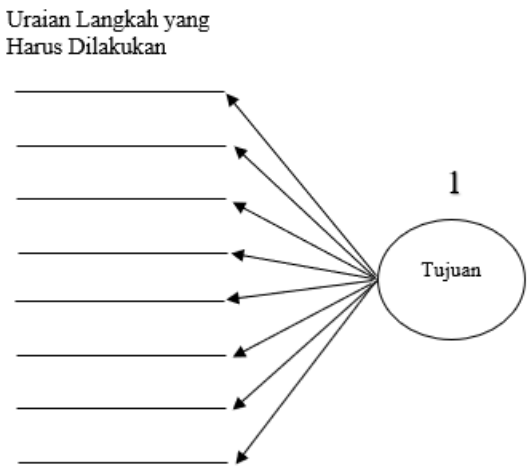

Gambar 2. Perumusan Tujuan dengan Metode Backward

Dalam merumuskan tujuan dengan metode backward, dilakukan dengan fokus merumuskan tujuan terlebih dahulu kemudian diikuti dengan mengurai langkah-langkah yang harus dilakukan untuk mencapai tujuan yang telah dirumuskan. Pendekatan ini merupakan hal yang baru bagi peserta pelatihan dan dilanjutkan dengan simulasi.

\section{Pendampingan bagi UMKM}

Pendampingan bagi UMKM merupakan tindaklanjut dari pelatihan yang dilaksanakan. Berkaitan dengan penguatan kelembagaan dilakukan pendampingan dalam pembentukan kelompok usaha bersama pelaku usaha kuliner di Cangakan, Karanganyar. Berkaitan dengan kewirausahaan dilakukan pendampingan bagi UMKM dalam merumuskan tujuan.

Setelah mendapatkan materi penguatan kelembagaan, peserta pelatihan yang juga pelaku usaha kuliner di Cangakan, Karanganyar menjadi termotivasi untuk membentuk kelompok usaha bersama. Pembentukan kelompok usaha bersama didampingi oleh Tim Pengabdian. Sebagai permulaan, peserta pelatihan dibagi ke dalam beberapa kelompok agar memudahkan koordinasi antara anggota dan efisiensi kelompok. Dalam pendampingan pembentukan kelompok usaha bersama juga dijelaskan mengenai kiat-kiat dalam membentuk dan memelihara kelompok agar tetap terjaga kebersamaannya dan memberikan manfaat ke semua anggota kelompok.

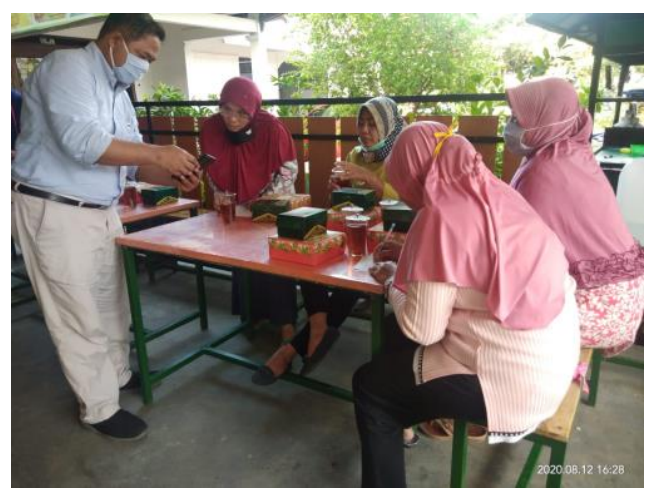

Gambar 3. Pendampingan Pembentukan Kelompok Usaha Bersama

Selain itu juga diberikan pendampingan mengenai penyusunan program-program dalam rangka menumbuhkembangkan kelompok usaha bersama sehingga keberadaannya tidak menjadi

$$
\text { Ekonomi, Sosial, dan Budaya }
$$


beban masing-masing anggota tetapi memberikan manfaat bagi anggota kelompok. Pada saat yang bersamaan, terdapat informasi bantuan bagi UMKM pada masa pandemi COVID-19 dari Pemerintah Daerah Kabupaten Karanganyar, Tim Pengabdian juga mendampingi dalam memanfaatkan teknologi informasi untuk memanfaatkan program tersebut. Pembentukan kelompok usaha bersama tentu saja perlu ditindaklanjuti pada proses pengurusan legalitas kelompok untuk mendapatkan pengakuan dari dinas terkait. Pengurusan legalitas kelompok juga didampingi oleh Tim Pengabdian.

Berkaitan dengan materi kewirausahaan, pendampingan dilakukan bagi UMKM dalam perumusan tujuan dan langkah-langkah untuk mencapai tujuan. Pendampingan dilakukan secara intensif dan individual kepada masing-masing peserta pengabdian. Masing-masing diberikan lembar kerja seperti yang disajikan pada Gambar 2 untuk diisi dan dievaluasi oleh Tim Pengabdi dan diberikan penilaian mengenai aspek kecukupan pemenuhan indikator-indikator dalam perumusan tujuan.

\section{KESIMPULAN}

Simpulan dari kegiatan pengabdian masyarakat ini menunjukkan bahwa pelaku usaha kuliner di Cangakan, Karanganyar masih bersifat individual. Semua pelaku usaha yang menjadi mitra dalam pengabdian masyarakat ini belum memiliki ijin usaha dan belum mengenal tentang kelembagaan.

Melalui program pengabdian masyarakat dengan bentuk pendidikan kepada masyarakat, pelaku usaha dikenalkan tentang prinsip dasar kelembagaan, arti pentingnya kelembagaan bagi sebuah usaha khususnya usaha mikro, kecil, dan menengah. Selanjutnya diberikan pelatihan dan pendampingan dengan metode role play tentang bagaimana membentuk kelompok serta programprogram yang relevan untuk menunjang keberlanjutan usaha khususnya bagi pelaku usaha yang kurang mampu dalam hal permodalan usaha.

Di akhir program pengabdian, sudah mulai muncul inisiasi peserta untuk membentuk Kelompok Usaha Bersama (KUBE) kuliner Cangakan, Karanganyar dalam rangka mewadahi seluruh pelaku usaha kuliner di Cangakan,
Karanganyar dengan tujuan melindungi UMKM Kuliner Cangakan, Karanganyar agar usahanya berkelanjutan.

\section{UCAPAN TERIMAKASIH}

Terima kasih kepada Universitas Sebelas Maret yang telah menyetujui Program Hibah Pengabdian kepada Masyarakat dengan No. Kontrak 453/UN.27.21/PN/2020.

\section{REFERENSI}

Barney, JB. (2002). Gaining and Sustaining Competitive Advantage. New Jersey : Pearson Education, Inc.

Bowen, SA. (2018). Mission and Vision. The International Encyclopedia of Strategic Communication. John Wiley \& Sons, Inc.

Khairunnisa, Saleh A, Anwas, OM. (2019). Penguatan Kelembagaan Petani Padi dalam Pengambilan Keputusan Adopsi Teknologi IPB Prima. Jurnal Penyuluhan, 15 (1), 89-96.

Kusmanto, H. \& Warjio. (2019). Pentingnya Legalitas Usaha bagi Usaha Mikro Kecil dan Menengah. Jurnal Pendidikan Ilmu-ilmu Sosial, 11(2): 320-327.

Meyer, PJ. (2003). Attitude Is Everything: If You Want to Succeed Above and Beyond. Attitude \& Motivation, 2. New York: Paul J. Meyer Resources

Riduwan, A. (2016). Pelaksanaan Kegiatan Pengabdian Kepada Masyarakat Oleh Perguruan Tinggi. Jurnal Ekonomi dan Keuangan, 3(2): 95107

Rismiyanto, E., Danangdjojo, T. (2015). Dampak Wisata Kuliner Oleh-oleh Khas Yogyakarta Terhadap Perekonomian Masyarakat. Jurnal Maksipreneur, 4 (1): 46-64.

Taiwo, AA., Lawal, FA., Agwu, MA. (2016). Vision and Mission in Organization: Myth or Ekonomi, Sosial, dan Budaya

1023 
Heuristic Device? The International Journal of Business \& Management, 4 (3): 127-134.

Mustaqim, FA., Kusnandar, Agustono. (2018). Analisis Kelembagaan dan Strategi Peningkatan Daya Saing UMKM Emping Melinjo di Kabupaten Magetan. Jurnal Sosial Ekonomi Pertanian dan Agribisnis, 14 (2): 124-134.
Yuniati, S., Susilo, D., Albayumi, F. (2017). Penguatan Kelembagaan dalam Upaya Meningkatkan Kesejahteraan Petani Tebu. Prosiding Seminar Nasional dan Call For Paper Ekonomi dan Bisnis, 498-505. 